\title{
TAKING OF THE LAND FOR THE PUBLIC NEEDS IN KLAIPE்DA DISTRICT
}

\author{
Rimvydas Gaudèšius \\ National Land Service under the Ministry of Agriculture \\ E-mail:Rimvydas.Gaudesius@nzt.lt \\ doi:10.13165/VPA-13-12-4-05
}

\begin{abstract}
Society development and economic necessity for the economic growth determine the use ofland for the public needs. These requirements reflect the public interest, and the state by performing its functions obligates to assure and meet them. In Lithuania, most of the land to be used for societal needs is in the urbanized territories or near them. When city boundaries expand and activity scope in the city centers grows, it leads to the higher demand of engineering networks and areas of common use. To protect cities from traffic overflow, bypasses are constructed. Other land is necessary for construction of buildings of economical and social purpose, development of cemeteries, exploitation of minerals, construction of pipelines, electrical networks and other communications. Objects that require approval from state institutions to use land for the public needs are specifically determined in the Law on Land of the Republic of Lithuania. The implementation of the regulations of this law causes most problems related to consistency of private land owners', interests and public (social) interests.

By carrying out researches, territorial planning documents were analyzed, based on which the land plots are taken for the public needs in the Klaipeda district. There are projects for the development of the Klaipeda Free Economic Zone, construction of the Palanga Bypass and building a high voltage electrical power line. This contribution reviews the course of this process and related problems and offers modifications that should facilitate the organizational procedures of taking the land and accelerate the process itself.
\end{abstract}

Keywords: taking land for the public needs, land administration, territory planning, property rights.

Raktažodžiai: žemès paèmimas visuomenès poreikiams, žemés administravimas, teritoriju planavimas, nuosavybès teisès 


\section{Introduction}

The Constitution of the Republic of Lithuania is the main law of the state regulating the aspects of social life, determining fundaments of the political, legal and economical system of Lithuania. Although Article 23 of the Constitution states that property shall be inviolable and it shall be protected by laws, yet there is an exception indicating that property may be taken in accordance with procedures established by law for the public needs with just compensation [4]. The Resolution of 6 May 1997 of the Constitutional Court of the Republic of Lithuania highlights the following: "The public interest is state authorized and protected by law, therefore, the implementation of it is one of the most important conditions of society existence and development." Social needs are identified as demands of the whole society or a part of it that has to be warranted and answered under the functions of the state and in accordance with the Constitution of the Republic of Lithuania; taking property for the societal needs has to be balanced among legitimate interests of the whole society members; public needs that property is taken for are always precise and expressed with reasonable certainty related to a particular property object; property may be taken (and justly compensated for) only for the public needs that may not be served objectively if a specific property object would not be taken.

The Law on Land of the Republic of Lithuania determines that land for public needs may be taken from private land owners only exceptionally under the resolution of the Head of National Land Service under the Ministry of Agriculture (thereinafter - National Land Service) based on the application of the state institution or municipal council, whereafter the land, according to the special or detailed plans, prepared under the procedures of the law on territory planning and fulfilling public interests, is necessary for the following:

1) the realization of state relevant economical projects, the importance of which is authorized by the decision of the Seimas or the Government;

2) the security of the country and state borders;

3) the international airports, national airfields, national ports and their equipment;

4) the public railway service facilities, roads, pipelines, high voltage electricity lines as well as the socially used engineering buildings required for the exploitation of the aforementioned;

5) the development of social infrastructure, i. e. construction (arrangement) and maintenance of objects for education and science, culture, health security and care, environment protection, social security, public security, physical education and sport development;

6) the maintenance of explored mineral resources;

8) the building (arrangement) and maintenance of municipal waste management (dumps);

9) the building and exploitation of objects for cemeteries and their maintenance;

10) the territorial complexes of nature and cultural heritage and objects (values) for defense [13]. 
The law passed on 12 April 2011 [14] determines the fundamentals, conditions and procedures of taking the land for the society needs in the Republic of Lithuania, when the land is necessary for the implementation of the special projects of national importance. The provisions of Chapter VIII of the Law on Land of the Republic of Lithuania and regulations implementing the provisions are not applicable to the procedures determined by the law (12 April 2011) of land taking for the needs of society. A special project of national importance is a project of energy infrastructure, transport infrastructure or areas of national defense, which is determined in accordance with procedures established by the law and applied by the Government, is authorized by the Seimas of the Republic of Lithuania as a notably relevant economical project for the state or strategically significant for the national defense.

The procedures of taking over the property for the needs of society in the course of time are becoming more detailed and advantageous for the initiators of land taking, however, it is often necessary to debate with landlord right defenders whether in general it is acceptable to alienate the property of the citizens. E. Švilpaite summarizes the topic of property restrictions and reviews not only the Constitution and international legislations, but also the Convention for the Protection of Human Rights, and states that "Neither Constitution, other legislations nor universally recognized international conflicts of law shall disprove the opportunity to restrict property rights in accordance with conditions and procedures established by law" [19]. Z. Namavičius and S. Stačiokas say that "Human rights and freedoms, first of all, are individual values. Rights and freedoms of every human and their realization "bump" into the rights and freedoms of another individual and their realization as well as to the public interests and state interests. All these interests must be harmonized to guarantee social order and balance of interests" [15]. By the Resolution of 2 October 2001, the Constitutional Court of the Republic of Lithuania pointed out that limitation of rights must be followed by the principle of proportion: "Establishment of responsibility by law as well as its implementation must be kept with the right balance between societal and personal interests to avoid untenable restriction of human rights. Based on this principle, human rights might be restricted only in so far as necessary to protect the public interests; a reasonable proportion has to be sustained between the chosen remedies and attainable legitimate and socially important purpose. To reach this purpose the determined remedies may be sufficient to restrict the human rights yet not more than necessary."

Notably, land utilization for the public needs (construction of roads and other communications, infrastructure objects, etc.) increases the development possibilities of adjacent land plots and so their market value. E. Ramanauskas points out that benefit received by all land owners is not properly estimated while planning territory and land management modifications: "After the land was used for the public needs the owners of other land plots usually use the infrastructure created by the state or municipality although they did not contribute to the establishment of infrastructure. Due to such uneven loss severance the problem of the principle of justice arises. If this principle is disregarded, owners who suffer losses gain a legitimate matter to pursue protection of their property 
by changing planning solutions, ignoring their quality" [17]. Yet, the compensation for the taken land comprises most of the problems for the land planners in making decisions regarding the taking of the land.

D. Stikliūnas, who analyzed the procedures of taking of the land for the public needs in Latvia and Estonia, indicates that these countries also have a possibility to take private land for the public needs for just compensation. In Latvia, they offer to compensate not only the available value of the land plot, but also income that may be received within the period of 5 years from the activity pursued before the alienation. In Estonia, the cases of taking of the land for the public needs are more elaborated. It is also noted that there is an opportunity for the former owner to regain the possessed property when it becomes expendable for the society [18].

Land plot taken for the public needs is assessed according to the direct value comparison method, in accordance with the procedure of the property and business value system and requirements [8], i. e. considering the method and nature of land utilization, land plot location in regard to residential territories or recreational objects, kinds of plant life and landed property within the land plot, etc. Not necessarily the whole land plot might be taken for the public needs, but only the part, which is projected in the special territorial planning documents, as required by the building or arranging the respective object. However, the damage for the former owner is compensated not only for the part of the plot taken, but also for the depreciation difference of the remaining land plot, which emerges due to the built or arranged object next to that land plot. Namely, the biggest problem, which impedes the implementation of the given objects, is disagreement of the citizens with the compensated value for their taken property. Landlords maliciously attempt to obtain the biggest financial benefit possible from the construction of the objects of national importance, therefore, contentions and court are often inevitable solutions in such cases.

It should be noted that court decisions are normally in favor of the landlords, who make complaints, because according to the Supreme Court of Lithuania, "the landlord of the property is the weaker party in the case of taking the land for the public needs, therefore, the decision made by the person regarding property alienation, in case of a dispute, must immediately go to law and substantiate the necessity of property alienation during the trial stage as well as justify the means of proposed reward and compensation. In cases of doubt regarding the reward and conditions, they ought to be favorable to the weaker party of the dispute, unless the weaker party is proved to have abused its rights" [3].

The aim of the research is to analyze territorial planning documents prepared in Klaipeda district that are necessary for the taking of the land for the public needs and determine characteristic problems related to their preparation and implementation. The following tasks have been set for the implementation of the aim:

- analyze the particularities of taking of the land for the public needs in the Klaipeda Free Economical Zone (Klaipeda FEZ);

- analyze a special plan for the construction of the Palanga Bypass;

- analyze the taking (use) of the land for the construction of a new high voltage electricity line;

- prepare the proposals regarding the specifications regulating the procedures of 
taking of the land.

The object of the research is special territorial planning projects prepared in the Klaipeda district to take private persons' land for the public needs.

The methods of the research are analysis of legislations and special planning documents, dissociation and deductions. Drawings given hereinafter have been prepared using the AutoCAD program, information of the orthographic map and map information of the Real Estate Cadastre managed by the State Institution Registry Centre.

\section{The Results of the Research}

\section{The Development of the Klaipèda Free Economical Zone}

The development of the Klaipeda Free Economical Zone (thereinafter - FEZ) has a special importance for state economy, however, in this case, the process of taking of the land was not smooth either. The procedures were started under the Note of 25 April 2005 of the Klaipeda City Municipality Administration and Orders of 27 May 2005 and 29 August 2005 of the Head of the Klaipeda County, based on which a decision had been made to start the procedure of taking of the land for the public needs in Lypkiai and Svepeliai villages, necessary for the Klaipeda FEZ development. This decision was appealed to a court by the landlords. Acting on a complaint, the Klaipeda Regional Administration Court by the Resolution of 15 November 2005 in the administrational case abolished the aforementioned orders, stating that the Klaipeda City Municipality Administration, before submitting the application regarding the taking of the land for the public needs, was supposed to inform the landlords on this matter in a written form and indicate precise aims of taking of the land for the public needs, however, this imperative law requirement was not implemented. The case lasted for 11 months.

Under the Orders of 18 July 2006, the Head of the Klaipeda County for the second time started the procedure of taking of the private land for the public needs, however, the landlords appealed this decision to the court, and on 15 December 2006 the Klaipeda Regional Administration Court again abolished the Order of the Head of the County, stating that the Head of the Klaipeda County started the procedure without indicating free national land plots in the site boundaries plan (which could be a compensation for the landlords instead of money). This time the case lasted for 5 months [7]. As the sequel of the events shows, none of the landlords subsequently declared intention to attain an equivalent plot of the land, but demanded financial compensation.

Due to fast development of the FEZ territory (in the national land), an increasing number of investors and construction of buildings for a full functioning of the companies, later local residents addressed the Municipality with requests to solve the issue of their prompt dispossession from the industry protection zone [21]. On 5 May 2007, for the third time, the Klaipeda City Municipality Administration addressed the Head of the Klaipeda County in a written form regarding the preparation of the project. The Head of the Klaipeda County validated the Note by an order and again started the procedure of taking of the land 
for the public needs. The outcomes of the procrastination to commence the work were mainly of economical nature: the price of the property to be taken for the public needs was deemed to have increased by several times during the proceeding period.

The request to take the land for the public needs was submitted in accordance with the Law on Land, Art. 45 (10). The Government of the Republic of Lithuania by Resolution No. 1094 of 14 October 1999, Regarding the Acknowledgement of Free Economical Zones to be the Economical Projects of National Importance, acknowledged the Klaipeda FEZ as an economical project of national importance.

The location of the land plots to be taken in the former Lypkiai village is presented in Figure 1. Most of the decisions regarding further territory handling have already been described in detailed plans authorized by the Resolutions of 20 March 1997 and 28 September 1997 of the Klaipeda City Municipality Administration.

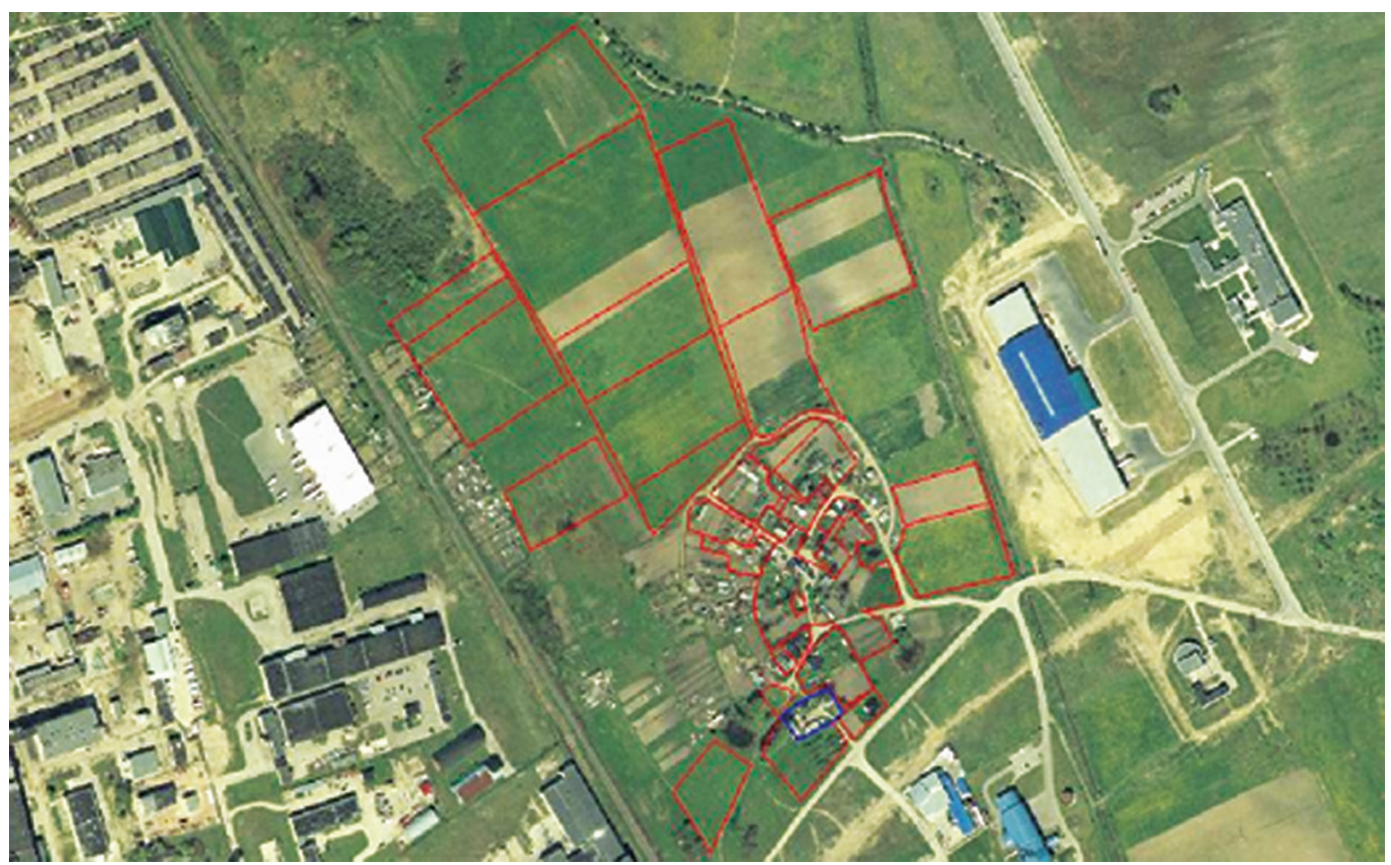

Figure 1. Taking of private land for the development of the Klaipeida

Free Economical Zone

Source: Klaipeda FEZ Development Project

The territory to be taken for the public needs is 12.6704 ha, 2.1064 ha of which are of other purpose and 10.564 ha are the plots of agricultural land. The projected area was composed of 32 land plots, 19 of which were agricultural land. 26 owners (11 of which were co-owners) of the plots participated in the project. 5 people did not agree with the estimated value of their former property and did not sign the agreement regarding loss compensation due to the taking of the land for the public needs and appealed the project, 
therefore, these owners drew up the statements with a slight change of the recalculated value. The alienation of the plots within the whole FEZ territory proceeded in several stages, as a result, the area of the plot taken and the number of plots varied throughout the stages (Table 1).

Table 1. Data about land plots taken for the public needs in the Klaipèda Free Economical Zone in Lypkiai village

\begin{tabular}{|c|c|c|c|c|}
\hline Landlord & $\begin{array}{l}\text { Total area } \\
\text { of plots, ha }\end{array}$ & $\begin{array}{l}\text { Purpose of the use } \\
\text { of the land plot }\end{array}$ & $\begin{array}{l}\text { Number of land } \\
\text { plots belonging } \\
\text { to the landlord }\end{array}$ & $\begin{array}{c}\text { Owner of the land plot agreed } \\
\text { (disagreed) with } \\
\text { the compensation sum } \\
\text { due in the agreement }\end{array}$ \\
\hline \multirow{2}{*}{ A } & 0.1254 & Other & 1 & \multirow{2}{*}{ Agreed } \\
\hline & 1.7529 & Agriculture & 5 & \\
\hline B & 1.4511 & Agriculture & 3 & Agreed \\
\hline \multirow{2}{*}{$\mathrm{C}$} & 0.2700 & Agriculture & 1 & \multirow{2}{*}{ Disagreed } \\
\hline & 0.0923 & Other & 1 & \\
\hline \multirow{2}{*}{$\mathrm{D}$} & 1.0900 & Agriculture & 2 & \multirow{2}{*}{ Agreed } \\
\hline & 0.0496 & Other & 1 & \\
\hline $\mathrm{E}$ & 0.1000 & Agriculture & 1 & Agreed \\
\hline $\mathrm{F}$ & 0.5700 & Agriculture & 1 & Agreed \\
\hline \multirow{2}{*}{ G } & 0.7600 & Agriculture & 1 & \multirow{2}{*}{ Agreed } \\
\hline & 0.2547 & Other & 1 & \\
\hline $\mathrm{H}$ & 1.4500 & Agriculture & 2 & Agreed \\
\hline I & 2.9700 & Agriculture & 2 & Agreed \\
\hline $\mathrm{J}$ & 0.0577 & Other & 1 & Agreed \\
\hline $\begin{array}{c}\mathrm{K}, \mathrm{L}, \mathrm{M}, \\
\mathrm{N}\end{array}$ & 0.1500 & Agriculture & 1 & 2 agreed, 2 disagreed \\
\hline $\mathrm{O}$ & 0.3397 & Other & 3 & Agreed \\
\hline $\mathrm{P}$ & 0.0314 & Other & 1 & Agreed \\
\hline $\mathrm{R}$ & 0.0153 & Other & 1 & Disagreed \\
\hline $\mathrm{S}$ & 0.0737 & Other & 1 & Agreed \\
\hline $\mathrm{T}$ & 0.1939 & Other & 1 & Agreed \\
\hline $\begin{array}{c}\mathrm{U}, \mathrm{V}, \mathrm{Z} \\
\mathrm{Q}, \mathrm{W}, \mathrm{X} \\
\mathrm{Y}\end{array}$ & 0.8727 & Other & 1 & 6 agreed, 1 disagreed \\
\hline
\end{tabular}

Source: Klaipeda FEZ Development Project

The Government of the Republic of Lithuania by Resolution No. 1038 of 14 July 2010, Regarding the Confirmation of Residents Eviction from the Klaipeda Free Economical Zone Program, made a preliminary budget of LTL $22200 \mathrm{k}$ for redemption of the land plots taken for the public needs and realty included (buildings and dwellings) and other needs. According to the capacity determined by the property assessors in 2007, land taken 
for the public needs costs LTL $500 \mathrm{k} / \mathrm{ha}$ for agriculture purpose land and LTL $22 \mathrm{k} / \mathrm{ares}$ for the land of other purpose. Nevertheless, the value of recoverable planting for the landlords comprised LTL $8.1 \mathrm{k}$, buildings value was LTL $4001.8 \mathrm{k}$.

Success of industrial territories depends on their location, development and management, which is one of the key factors of the overall FEZ activity success and attraction for the investors. Compared to the Kaunas FEZ, the Klaipeda FEZ has a specific boundary feature. Territory necessary for the infrastructure is eliminated from the total FEZ boundary and in this way many small-sized separate plots are defined, which are allocated by corridors excluded from the territory (these territories belong to the municipality), necessary for the FEZ infrastructure. Hereby, the main operator and investors, naturally, avoid expenses for the development and maintenance of the infrastructure.

The total area of the Klaipeda FEZ is 412 ha, however, the area authorized by the Government reaches only 293.9 ha and by the year 2008 this development absorbed 11 ha more than it was scheduled [6]. Therefore, it may be forecasted that this territory is going to expand in the future. Taking of previously mentioned plots lasts for more than a decade due to the litigations started by the private persons, while the price for the property to be taken for the public needs during this period has increased several times [7]. It is possible, though, that long-lived projects and troublesome procedures will not be necessary for the development of FEZ territories.

During recent years, the land belonging to private persons $(87.3 \mathrm{ha})$ has been included in the territory of the Klaipeda FEZ without planning to redeem it. According to the representatives of the Ministry of Economy, "legal acts do not establish whether state or private land shall be let to the FEZ management company." In such a case, the FEZ management company will let private land located in the territory of the FEZ and later will sublet it to the investor of that land. Consequently, private natural or legal persons as the owners of the land in the Klaipeda region will be involved in the activity of the FEZ, as they will be in control of the land intended for industrial activity [6].

\section{The Construction of the Liepaja Road 24.8-35.5 (Palanga Bypass)}

On 6 December 2002, the Palanga Municipal Council endorsed the special plan of the Liepaja Road 24.8-35.5 km construction (thereinafter - Palanga Bypass). The emplacement organizer was the Lithuanian Road Administration.

Need of the Palanga Bypass was projected in 1979, when the Republican Industrial Road Administration assigned the engineers to explore the possibilities to reconstruct the Klaipeda-Liepaja Road, starting from Klaipeda up to the Latvian border. A building obstructed the widening of the central Palanga street across the town, therefore, a decision was made to build a new road, which would reduce transport flow in the town, especially during the summer season. The construction of the Klaipeda-Liepaja Road was implemented in stages, starting in 1984 on the Klaipeda-Normantai Road. Presently, there is one stage left unimplemented - arrangement of the Palanga Bypass (Figure 2). 
Preparing a special plan for the Palanga Bypass, two options were projected, according to which a road may be constructed and a different number of private land plots may be alienated. In 1991, it emerged that the Palanga Airport was not going to be eliminated, moreover, it would be expanded under the international standards. Therefore, an option acceptable to several concerned groups was chosen: a complete bypass will not only improve ecological conditions in the resort and will prevent pollution, but also will open an opportunity to rearrange the Palanga Airport under the international standards.

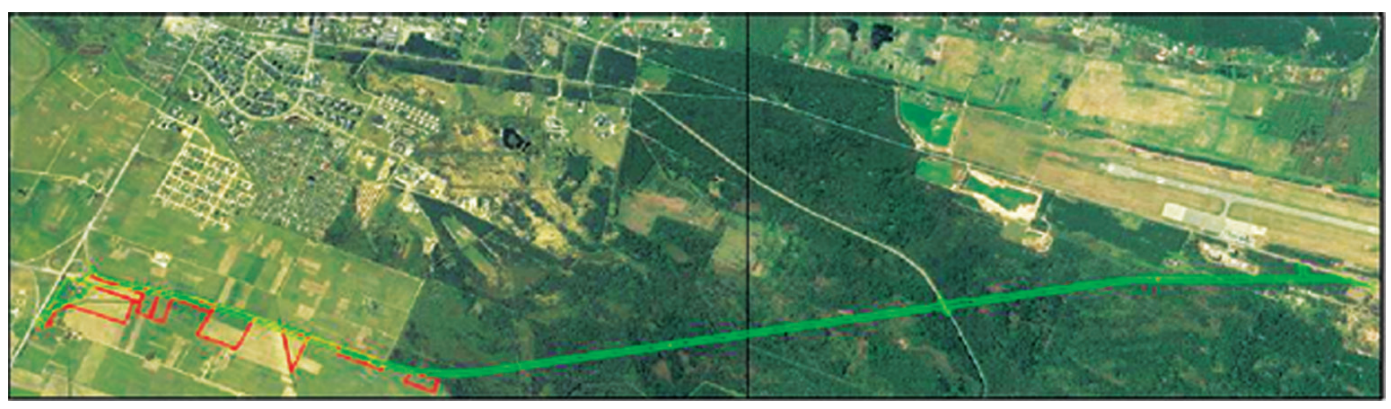

Figure 2. Palanga Bypass

Source: State Institution Registry Centre

Alienation of land plots for the road construction will affect only the land plots located in the Kretinga Region Municipality. The other side of the road belongs to the Palanga Municipality and a stretch of state forest in that area will be taken, as well. Based on the State Institution Registry Centre, it was found that 25.1 ha of the land will have to be taken for the construction of the Palanga Bypass (16.63 ha of forests, 0.80 ha of other purpose). In most cases, only the mentioned parts of plots will be taken out of 18 land plots. One homestead is planned to be demolished.

The special plan does not indicate a precise location for restoration of forest to compensate deforestation for the road construction. The owners of the adjacent land plots will accordingly be able to demand planting for protection alongside the road, which would allow continuing agricultural or other activity in the road safety zone $(70 \mathrm{~km}$ towards both sides from the brim of the road embankment). Many disagreements and questions rose while trying to align the project to the society regarding the compensation as well as the approach to the land plots. The project alignment protocol provides that the land plots join together, therefore, there will be only one common driveway to the plots [2].

It will be the first infrastructural project in the country, implemented under the pattern of public and private partnership. Lithuanian and foreign companies requested to participate in the competition of this project. The company, the winner of the competition, shall oblige to construct the bypass within two years and maintain and reconstruct it for another 23 years. The tentative project value is LTL $88.6 \mathrm{~m} \mathrm{[16].}$ 


\section{The Construction of the Klaipėda-Telšiai $330 \mathrm{Kw}$ Electricity Transmission} Air Line

As mentioned above, not necessarily the whole land plot should be taken for the public needs, e.g., in case of electricity line construction or other rather narrow engineering communications (heating, gas, oil, etc.), a part of land plot is enough to be taken to serve the engineering networks. $330 \mathrm{Kw}$ Electricity Transmission Air Line Klaipèda-Telšiai (thereinafter $-\mathrm{AL}$ ) is unique because the project will be implemented by choosing a different method, i. e. by determining easement for the plots (Figure 3), but not by redeeming a whole lot of land plots.

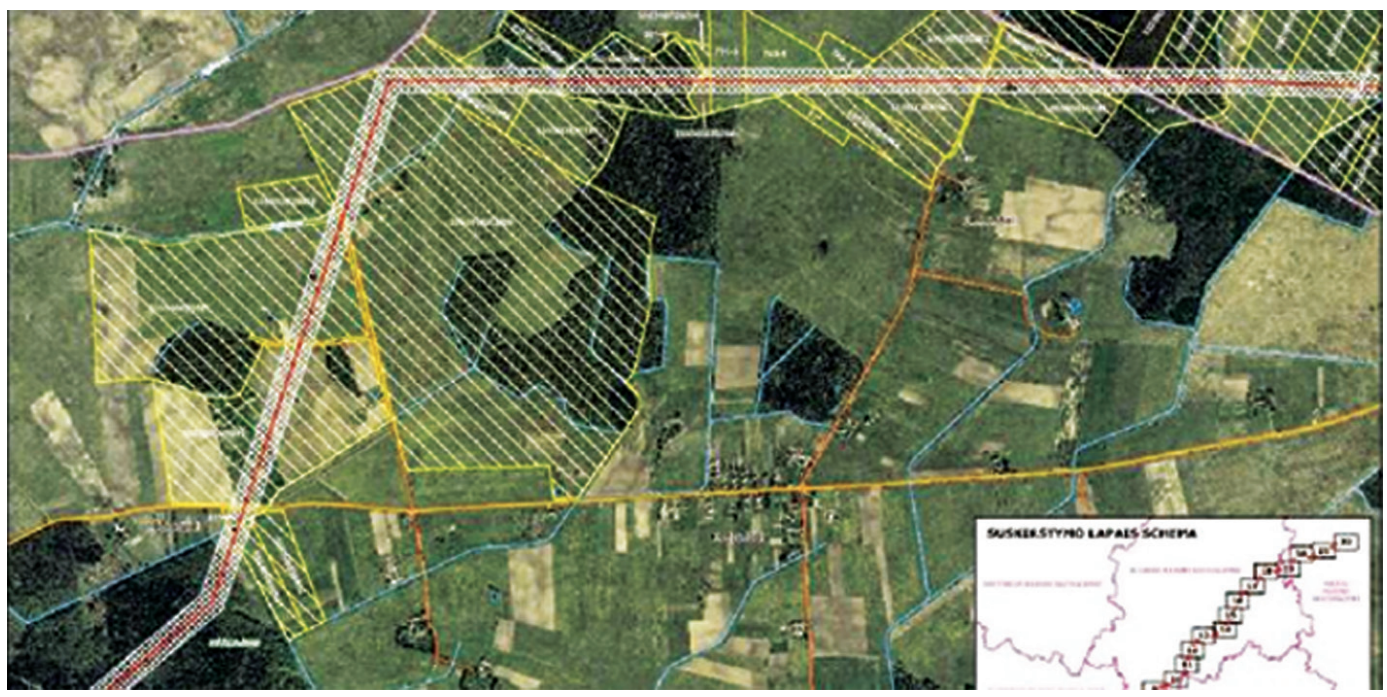

Figure 3. Part of the land plots with the set easement for the power line construction

Source: Special territorial planning document of $330 \mathrm{Kw}$ Electricity Transmission Air Line Klaipèda-Telšiai

The background of the special planning is Order No. 4-222 of 27 May 2008 by the Minister of Economy of the Republic of Lithuania, Regarding the Preparation of a Special Plan of $330 \mathrm{Kw}$ Electricity Transmission Air Line Klaipeda-Telšiai Construction. One of the goals of the special plan is to reserve territories for the target AL development, determine the requirements of their utilization, management, safety and other.

The electricity line is necessary not only for Klaipeda or Lithuanian regions; the meaning of the AL is estimated internationally. Electricity produced in Lithuania does not have a way to European Union countries, except for the Baltic States. After the construction of the high voltage electricity transmission AL, the conditions for the merge of the Lithuanian power grid with the Western European (power bridge Lithuania-Sweden) power grid will be fulfilled. 
AL special plan solutions do not contradict the solutions of the common plan of the territories of the Republic of Lithuania. Furthermore, they specify the engineering infrastructural solutions of the municipal plans for Klaipeda, Telšiai, and Plunge regions.

The route formed in the special plan solutions is to keep the longest distant possible away from the dwellings. In almost all planned territory, the route is formed to be not less than $250 \mathrm{~m}$ away according to the hygiene standards, only in more populous territories near Dovilai, Gargždai, etc., the planned AL is $100 \mathrm{~m}$ close to the homesteads. In order to evaluate the AL effect on inhabitants, an assessment report of the effect on public health has been prepared.

The chosen route does not cross the territories of immovable cultural properties and their safety zones. However, the route inevitably crosses the protected areas. While projecting the configuration of the route, the plots with prepared detailed territorial planning documents were tried to be bypassed. The territory of the AL was chosen based on the number of criteria that were classified under the importance (Scheme 1).

\begin{tabular}{|c|}
\hline $\begin{array}{l}\text { DISTANCE TO THE DWELLINGS } \\
\text { (HYGIENE STANDARD HN 104:2000) }\end{array}$ \\
\hline PASSING OF PROTECTED AREAS \\
\hline PASSING OF THE OBJECTS OF CULTURAL HERITAGE \\
\hline PASSING OF MINERAL-EXTRACTING AREAS \\
\hline SAFETY ZONES (under the special conditions of land and forest utilization) \\
\hline LANDOWNING \\
\hline FORESTS (Forest Cadastre) \\
\hline SOLUTIONS OF TERRITORIAL PLANNING DOCUMENTS \\
\hline TECHNICAL REQUIREMENTS FOR AIR ROUTE INSTALLATION \\
\hline RELIEF \\
\hline
\end{tabular}

Scheme 1. Power line route selection criteria according to the priority of importance Source: Special territorial planning document of $330 \mathrm{Kw}$ Electricity Transmission Air Line Klaipèda-Telšiai

The total AL Klaipeda-Telšiai route length is approximately $89 \mathrm{~km}, 36 \mathrm{~km}$ of which is in the territory of the Klaipeda Region Municipality. There are 260 private land plots in the territory of the Klaipeda Region Municipality (222 agriculture, 37 forest and 1 of other purpose), falling within the AL safety zone, the total area of which is 231.82 ha [22]. 
An easement will be determined in the land plots, falling within the safety zone limits of the planned air line route, enabling to build centralized (of common use) engineering infrastructural networks, use them and service them. Under the Law on Land, the easement does not serve as taking or redemption of the land; it provides a right to a foreign land plot or a part of it with determined activity restrictions within the area of the land plot. The landlords were provided with the agreements, which indicate the compensation for the damage due to the easement establishment and AL construction in their private land plots. However, in this project not all owners agreed with the compensations provided.

\section{Conclusions}

1. Land taken for the public needs is important for the state economic growth, as it helps to absorb European Union and various international structural funds, improves infrastructure, develops economic activity and in some cases reduces impact of city pollution on the residents.

2. New law editions allow the necessity, while preparing special territorial planning documents that enable to take private land for the public needs, to determine explicit limits for the territory projected based on cadastral data, to inform landlords about the proposal to take their plots for the public needs (without presenting the already made decision). Furthermore, institutions concerned willing to initiate the beginning of the project have to submit an explanatory note on the importance of the demand as well as to perform the cost-benefit analysis, which in detail presents information and estimation of predictable costs and benefit.

3. Taking land for the public needs has always lasted for many years and the extension of the period has been usually based on landlord complaints regarding the damage assessment. In order to avoid such problems, it is necessary to properly inform society about economic benefit for the owner and society of land utilization for a particular activity and present estimations based on different property assessment methods.

4. In view of valid legislations, it may be concluded that land lots operated in accordance with private people's property right for many years have been restricted by different criteria. Special conditions of land and forest use, easement, territorial planning documents also partly restrict persons' freedom to the property or use of the property according to their desirable and supposed needs. Therefore, specialists responsible for land policy implementation must explain better to the citizens the importance of the public interest by restricting property rights and that property owned by private persons does not only grant rights, but duties, as well.

5. A database has to be established involving information about the amount of the land taken for the public needs, number of objects, spatial resolution in the territory of Lithuania, etc. Also, to interconnect this database with other data layers and databases is necessary. Using different databases, it is possible to adjust taken territory plots and arrangements, considering not only private citizens interests or demands of project 
initiators, but also the ecological criterion and other valid territorial planning or strategic planning documentation.

\section{References}

1. Kūris E. Ūkinès veiklos laisvè, sąžininga konkurencija ir bendra tautos gerovė. Jurisprudencija, 2005, T. 64, Nr. 56, 5673.

2. Liepojos kelio 24,8-35,5 km (Palangos aplinkelio) specialusis planas. 2002.

3. Lietuvos Aukščiausiojo Teismo nutartis civilinėje byloje ,Dèl turto paèmimo visuomenès poreikiams ir kompensacijos“. Teismų praktika, 2003, Nr. 18.

4. Lietuvos Respublikos Konstitucija (priimta Lietuvos Respublikos piliečių 1992 m. spalio 25 d. referendume). http://www3.lrs.lt/home/Konstitucija/Konstitucija.htm [yyyy-mm-dd].

5. Lietuvos Respublikos teritorijų planavimo įstatymas. Valstybės žinios, 1995, Nr. 107-2391.

6. Lietuvos Respublikos Valstybès kontrolè. Valstybinio audito ataskaita Laisvųų ekonominių zonų ir pramoninių parkų vystymas. $2012 \mathrm{~m}$. rugsèjo $28 \mathrm{~d}$. Nr. VA-P-20-7-13. Vilnius.

7. Lietuvos Respublikos Valstybės kontrolè. Valstybinio audito ataskaita Žemès ir jos priklausinių igijimas ir naudojimas visuomenés poreikiams. $2009 \mathrm{~m}$. vasario $20 \mathrm{~d}$. Nr. VA-P-30-1-3. Vilnius.

8. Lietuvos Respublikos Vyriausybès 2005 m. rugpjūčio 25 d. nutarimas Nr. 924 „Dèl žemès paėmimo visuomenès poreikiams taisyklių ir žemės paėmimo visuomenès poreikiams projektų rengimo ir igyvendinimo taisyklių patvirtinimo“. Valstybès žinios, 2005, Nr. 104-3839.

9. Lietuvos Respublikos Vyriausybės 1999-10-04 nutarimas Nr. 1094 „Dėl laisvųjų ekonominių zonų pripažinimo valstybei svarbiais ekonominiais projektais“. Valstybės žinios, 1999, Nr. 842496.

10. Lietuvos Respublikos Vyriausybès 2010 m. liepos 14 d. nutarimas Nr. 1038 „Dèl gyventojų iškeldinimo iš Klaipėdos laisvosios ekonominès zonos programos patvirtinimo“. Valstybės žinios, 2010, Nr. 87-4595.

11. Lietuvos Respublikos Vyriausybės 2011-12-07 nutarimas Nr. 1422 „Dèl Klaipėdos laisvosios ekonominès zonos teritorijos ribų nustatymo“. Valstybės žinios, 2011, Nr. 151-7108.

12. Lietuvos Respublikos turto ir verslo vertinimo pagrindų įstatymas. Valstybès žinios, 1999, Nr. 52-1672.

13. Lietuvos Respublikos žemės įstatymas. Valstybės žinios, 2004, Nr. 28-868.

14. Lietuvos Respublikos žemès paėmimo visuomenès poreikiams igyvendinant ypatingos valstybinės svarbos projektus įstatymas. Valstybės žinios, 2011, Nr. 49-2362.

15. Namavičius Z., Stačiokas S. Viešųjų ir privačių interesų derinimas - darnios civilinès visuomenès ir teisinès valstybès principas. Jurisprudencija, 2008, T. 3, Nr. 105, 1626.

16. Palangos aplinkelio konkursas startuos balandi. http://www.ve.lt/naujienos/ekonomika/ ekonomikos-naujienos/palangos-aplinkkelio-konkursas-startuos-balandi-558942/ [2012-11-23].

17. Ramanauskas E. Teisinè žemės nuosavybės reikšmė teritorijų planavimui. Urbanistika ir architektūra, 2009, T. 33, Nr. 2, 8291.

18. Stikliūnas D. Žemės paėmimo visuomenės poreikiams procedūros. Kaunas: Lietuvos žemės ūkio universitetas, 2008.

19. Švilpaitė E. Konstitucija ir nuosavybès teisès apribojimo galimybės. Jurisprudencija, 2001, T. 30, Nr. 22, 6674. 
20. Švilpaitė E. Valstybės teisė riboti nuosavybės teisę pagal Europos žmogaus teisių konvencijos pirmąji protokolą. Jurisprudencija, 2003, T. 44, Nr. 36, 2336.

21. Žemès paėmimo visuomenès poreikiams, Klaipėdos laisvosios ekonominès zonos plètrai, buvusiuose Lypkių ir Švepelių kaimuose projektas. 2008.

22. $330 \mathrm{kV}$ elektros perdavimo oro linijos Klaipèda-Telšiai statyba. Specialusis planas. 2010.

\section{Rimvydas Gaudèšius}

\section{Žemės paėmimas visuomenės poreikiams Klaipėdos apskrityje}

Anotacija

Žemès panaudojimą visuomenès poreikiams lemia visuomenės vystymosi raida ir ūkio plètros ekonominis būtinumas. Šie poreikiai išreiškia viešąji interesą, kurị valstybè, atlikdama savo funkcijas, ịpareigota užtikrinti ir tenkinti. Lietuvoje daugiausia žemès, reikalingos panaudoti visuomenès poreikiams, yra urbanizuotose teritorijose arba greta jų. Plečiantis didžiųjų miestų riboms ir didejjant miestų centruose veiklos apimčiai, auga inžinerinių tinklų ir bendro naudojimo plotų poreikis. Saugant miestus nuo transporto srauto pertekliaus yra tiesiami aplinkkeliai. Kiti žemès plotai reikalingi pramoninès ir visuomeninès paskirties statinių statybai, kapinių plètrai, naudingųjų iškasenų eksploatavimui, dujotiekio, elektros tinklų ir kitų komunikacijų tiesimui. Objektai, kurie reikalauja valstybės institucijų sprendimo paimti žemę visuomenės poreikiams, yra konkrečiai nustatyti Lietuvos Respublikos žemės įstatyme. Šio įstatymo nuostatų igyvendinimas sukelia daugiausia problemų, susijusių su privačios žemès savininkų interesų ir viešųjų (visuomenès) interesų derinimu.

Atliekant tyrimus išnagrinėti teritorijų planavimo dokumentai, kuriais remiantis Klaipėdos apskrities teritorijoje yra paimami žemės sklypai visuomenès poreikiams - tai projektai Klaipėdos laisvosios ekonominès zonos plètrai, Palangos miesto aplinkkelio tiesimui bei aukštos įtampos elektros linijos tiesimui. Straipsnyje apžvelgiama šio proceso eiga ir iškilusios problemos, taip pat siūlomi pakeitimai, kurie turètų palengvinti žemès paėmimo darbų organizaciją ir paspartinti patị žemès paèmimo procesą.

Rimvydas Gaudèšius - Nacionalinès žemès tarnybos prie Žemès ūkio ministerijos vyriausiasis specialistas, kraštotvarkos magistras.

E. paštas: rimvydaskt144@gmail.com

Rimvydas Gaudèšius, Master of Environmental engineering, National Land Service under the Ministry of Agriculture, Chief Specialist.

E-mail: rimvy\daskt144@gmail.com

Straipsnis įteiktas redakcijai 2013 m. spalio 17 d.; recenzuotas; parengtas spaudai $2013 \mathrm{~m}$. spalio mèn. 